\title{
Microbubble-Mediated Delivery for Cancer Therapy
}

\author{
Richard J. Browning and Eleanor Stride *(1) \\ Institute of Biomedical Engineering, Department of Engineering Science, University of Oxford, Old Road \\ Campus, Oxford OX3 7DQ, UK; richard.browning@oncology.ox.ac.uk \\ * Correspondence: eleanor.stride@eng.ox.ac.uk; Tel.: +44-(0)-1865-617-747
}

Received: 26 September 2018; Accepted: 16 October 2018; Published: 19 October 2018

\begin{abstract}
Despite an overall improvement in survival rates for cancer, certain resistant forms of the disease still impose a significant burden on patients and healthcare systems. Standard chemotherapy in these cases is often ineffective and/or gives rise to severe side effects. Targeted delivery of chemotherapeutics could improve both tumour response and patient experience. Hence, there is an urgent need to develop effective methods for this. Ultrasound is an established technique in both diagnosis and therapy. Its use in conjunction with microbubbles is being actively researched for the targeted delivery of small-molecule drugs. In this review, we cover the methods by which ultrasound and microbubbles can be used to overcome tumour barriers to cancer therapy.
\end{abstract}

Keywords: ultrasound; cancer; drug delivery; cavitation; microbubbles

\section{Introduction}

Over the last century, many treatments have been developed to combat cancer. In combination with better understanding of the risk factors and diagnostic techniques, these have led to a fall in mortality. Unfortunately, late presentation and metastasis still confound many established techniques, and cancer is currently the second most common cause of mortality in the world [1]. The heterogeneity and complex microenvironment of solid tumours can make them highly resistant to treatment [2,3]. Many of the currently available drugs could be effective at a sufficient dose, but the lack of effective targeting means the severity of the side effects would be intolerable for the patient. Thus, there is a pressing need to develop methods to target drugs and so reduce the dose required whilst maintaining a therapeutic level in the tumour. Ultrasound is one such modality that has been demonstrated to improve the accumulation of drugs in target areas, and is itself a well-established technique with well-understood safety and usage. This review will introduce the mechanisms by which ultrasound, and in particular the combination of ultrasound and microbubbles, can mediate delivery.

\section{Solid Tumour Pathology}

Solid tumours develop as a result of dysregulation in cellular proliferation. Progressive accumulation of genetic mutations is necessary for solid tumour development, leading to the growth of a mass of cells in a discrete location within an organ or tissue [4,5]. As the cells towards the centre of the tumour become further distanced from blood vessels, they release stress signals which trigger angiogenesis from existing blood vessels to supply the tumour with oxygen and nutrients [6]. The tumour then continues to grow, eventually spreading locally out of the original location or metastasising to distant sites [7].

The challenge that the solid tumour microenvironment presents to drug delivery is a topic that has been well discussed in several reviews [8-10]. The primary issues are the poor vasculature and lack of lymphatic drainage. In particular, blood vessels in tumours are severely abnormal, having variable diameters and irregular or stagnant flow, and are prone to collapse and highly leaky (please 
see the recent review on tumour vasculature by Dudley et al. [11]). Without lymphatic drainage, waste materials and fluid leaking from the blood vessels remain in the tumour, resulting in a high local interstitial pressure. This is further compounded by the continued proliferation of cancer cells in a limited space, creating a highly dense mass of cells with a poorly defined extracellular matrix. The limited ability of the blood supply to carry therapeutics into the tumour, combined with the unfavourable convection gradient $[12,13]$, results in delivery being highly heterogeneous and limited largely to the periphery of the tumour. In addition, the poor supply of nutrients to tumours changes cell activity, making them highly resistant to the effects of multiple forms of therapy. For instance, hypoxia-a state of low oxygen tension-is a common issue in large tumours (see Figure 1) which severely impacts radiotherapy [2] and chemotherapeutics [14,15].

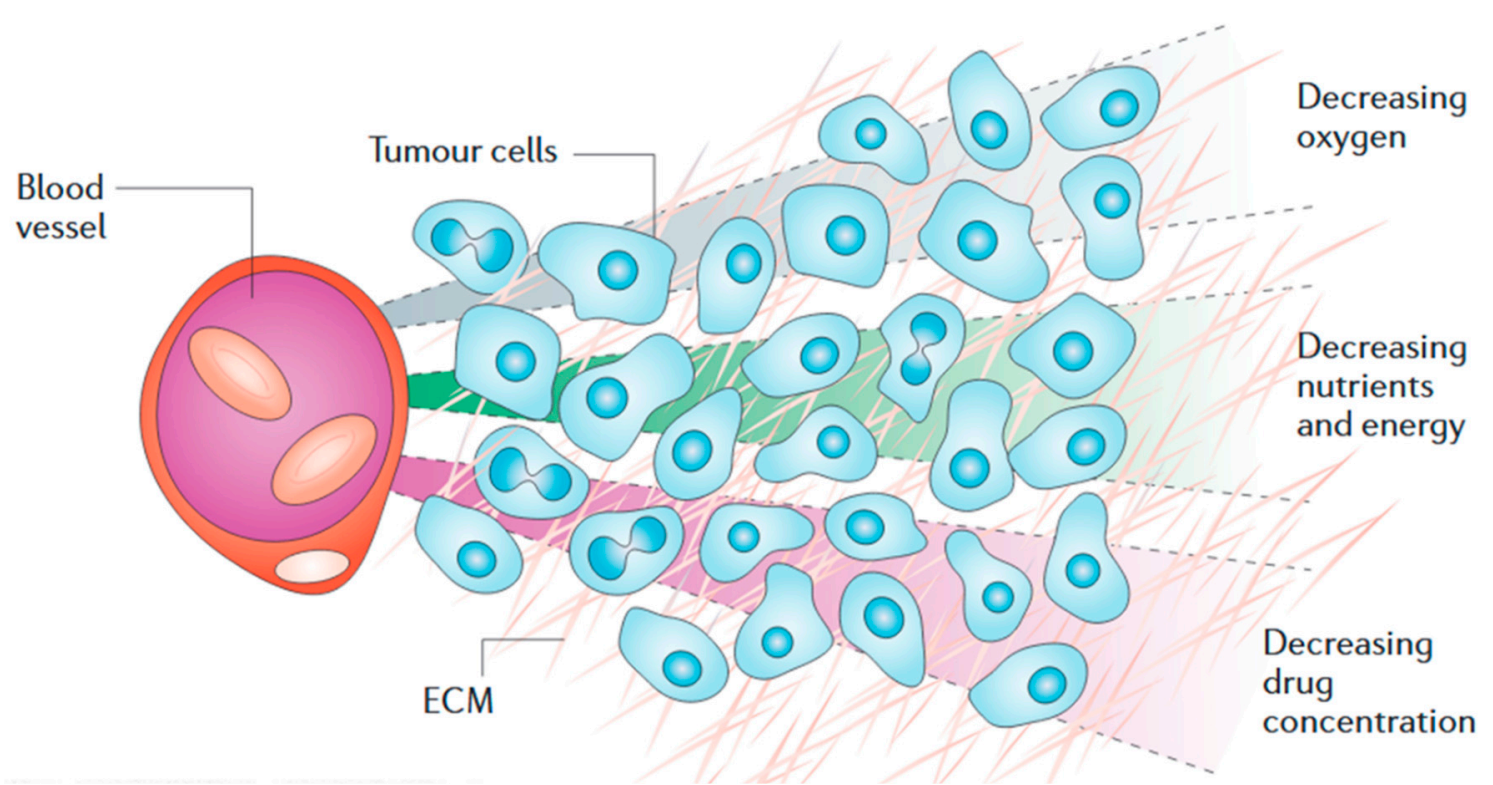

Figure 1. Schematic of the solid tumour environment. As distance from a blood vessel increases, the supply of oxygen, nutrients, and drug concentration becomes limited, leading to hypoxic, starved, and drug-resistant populations of tumour cells (ECM-extracellular matrix). Reprinted by permission from Springer Nature, Nature Reviews Cancer [10].

\section{Ultrasound}

The propagation and detection of high-frequency ( $>20 \mathrm{kHz})$ acoustic waves, i.e., ultrasound, in tissues is a long-established technique in diagnostic imaging [16]. Ultrasound waves are reflected as a result of differences in acoustic impedance between different tissue types, and the received echoes can be processed to create two- or three-dimensional images of structures within the body [17]. Depending upon the equipment used, images with millimetre spatial resolution at centimetre depths can be obtained, at frame rates capable of capturing tissue and fluid motion [18].

The attenuation of the acoustic energy in tissue can cause tissue motion, fluid streaming, and heating. For therapeutic applications, heating can be used for thermal ablation [19-21] or promotion of healing in physiotherapy [22,23]; whilst fluid streaming has been linked to transdermal sonophoresis [24] (see [25,26] for recent reviews). A further effect of the acoustic wave may be the production of cavitation, where a rapid fall in local pressure can cause the vaporisation and/or evolution of dissolved gases. As the acoustic pressure increases, the inertia of the surrounding fluid can cause the formed bubbles to violently collapse, and this process can cause significant damage to surrounding tissue or structures. Lithotripsy relies on this technique to fracture gallstones or kidney stones [27], although care must be taken to avoid cavitation in nontarget areas. This cavitation effect is also utilised for the sterilisation of equipment or liquids in sonication baths. At lower amplitudes, 
ultrasound may be used in conjunction with pre-existing bubbles or other cavitation nuclei to produce a range of mechanical effects that can be exploited for drug delivery. These are schematically shown in Figure 2 and discussed in more detail below.

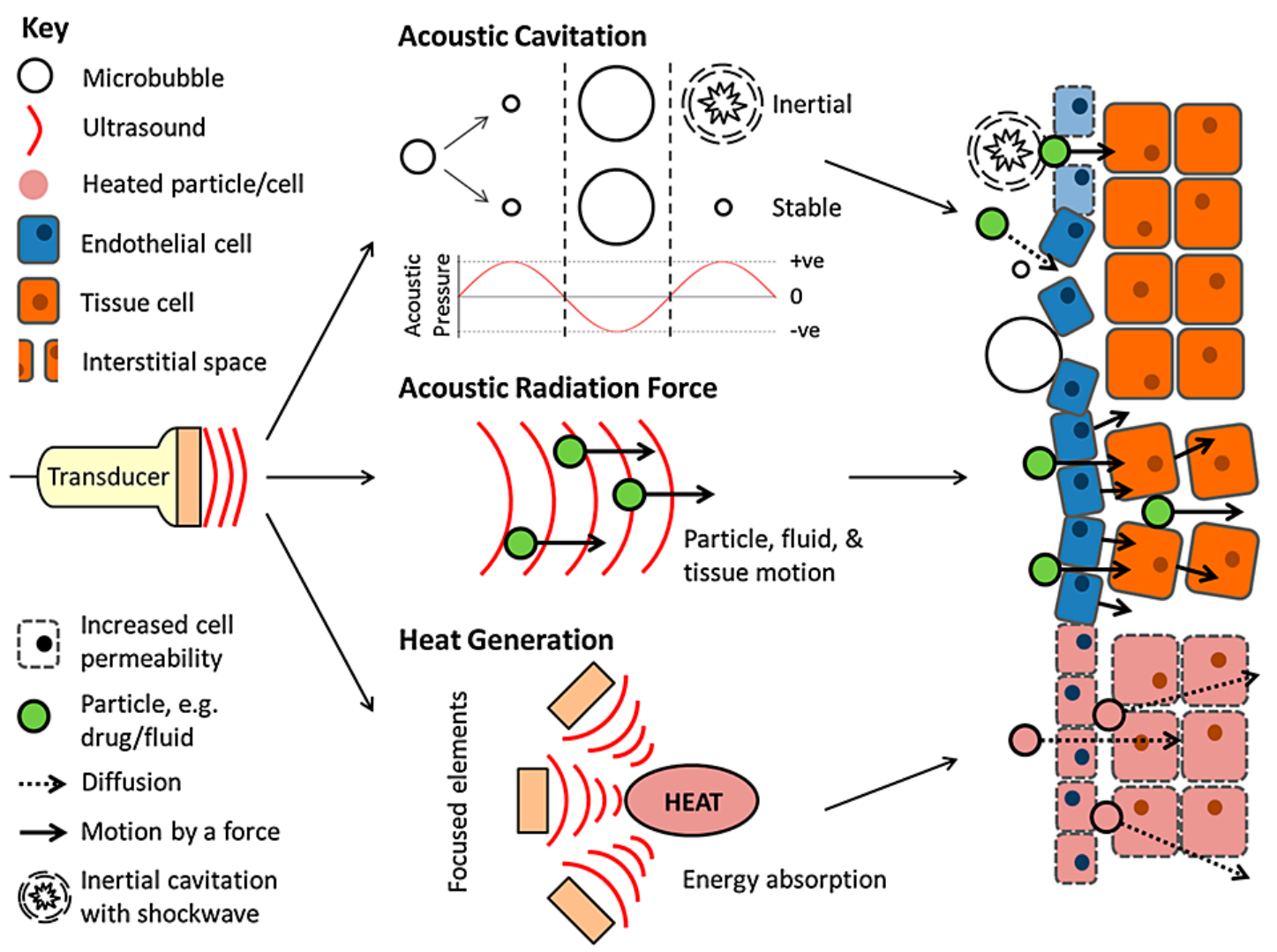

Figure 2. Illustration of mechanisms involved in ultrasound-mediated delivery. These can be divided into the mechanical effects of acoustic cavitation and acoustic radiation force, and thermal effects. Reprinted by permission from John Wiley and Sons, Journal of Labelled Compounds and Radionuclides [28].

\subsection{Thermal Delivery}

As ultrasound propagates through tissue, energy is absorbed, causing localised heating. The use of heat as a treatment tool, thermotherapy, is a well-established field. In particular, for tumour therapy, thermal ablation of diseased tissue is a clinically accepted form of treatment for solid tumours [29]. High-intensity focused ultrasound (HIFU) devices are designed to use tightly focused ultrasonic waves to thermally ablate tissue [30], and are typically combined with magnetic resonance imaging (MRI) for targeting and treatment monitoring. This combination has been highly effective for treating prostate cancers and uterine fibroids and is being trialled in a number of other cancers [30,31]. The tightly focused ultrasound enables lethal hyperthermia in the focal zone, whilst minimising destruction of surrounding healthy tissue. However, the focal zone is typically much smaller than the target tumour and treatment requires translation of the focus throughout the tumour, resulting in long treatment times. As the technique is noninvasive, discerning the boundary between tumour and healthy tissues can also be challenging [32].

There is therefore interest in combining HIFU with chemotherapy to help eliminate remaining cells, as is typically done in the case of surgical removal of tumours. Chemotherapy drugs administered concurrently to HIFU have been shown to achieve greater therapeutic effect. Research in this area is broad, with many drugs under investigation: doxorubicin [33,34]; docetaxel [35,36]; endostatin [37]; 
paclitaxel and estramustine [38,39]; adriamycin, mitomycin C, 5-fluorouracil, and cisplatin [39-41]; and gemcitabine [37,42,43].

Besides ablation, HIFU can be used to cause mild hyperthermia of tumours. Hyperthermia has a number of effects on tumours which can improve the effect and delivery of systemically delivered drugs. Increased temperatures lead to increased permeability of blood vessels and cell membranes in tumours [44,45] and increased diffusivity of drug molecules [46], ensuring greater penetration and uptake $[47,48]$. Additionally, drug delivery and effect may be improved as increased tumour temperatures reduce interstitial pressures and hypoxia [49,50]. A further factor is the immune system, which has a strong influence on tumour progression. Mild hyperthermia of tumours has been shown to improve immune cell infiltration [51], and the application of thermal energy is under consideration for enhancing both immune responses to traditional therapy and specific immune therapies (recently reviewed in [52]).

One popular use of mild hyperthermia by HIFU is the release of drugs from loaded nanoparticles. Numerous nanoparticles have been designed to take advantage of locally applied heat to a tumour location, and the topic has been reviewed extensively elsewhere [53-55]. As an alternative to drug delivery, acoustically responsive nanoparticles have also been used to enhance the thermal ablation effect to reduce the intensities and durations required for standard ablation. Nanoscale phase change agents encased in block copolymers have been used to increase damage in a tumour during HIFU $[56,57]$. Nanoparticles can passively localised in tumour regions by the enhanced permeability and retention effect or be purposefully trapped by the use of vascular obstructive agents, such as Lipodol. Subsequent vaporisation of the particles to generation micrometre-sized gas bubbles results in mechanical damage to the vasculature and blood supply, which could be further amplified by cavitation of the formed gas bubbles. Additionally, both iron and gold nanoparticles loaded on to polymer-based agents have been shown to enhance HIFU ablation damage [58,59].

\subsection{Mechanical Delivery}

Besides heat, ultrasound can also transfer momentum to the tumour due to the pressure gradient formed along the acoustic path. In fluids, this results in acoustic streaming [60], which has been postulated as a possible mechanism for delivery $[26,61,62]$. The effect of momentum transfer on solid tissues, i.e., acoustic radiation force (ARF), generates additional bioeffects of potential use in tumour delivery. It has been demonstrated that the motion induced by ARF can cause the disruption of tight junctions in endothelial tissues [63-67], resulting in increased uptake. Additionally, the macroscale tissue motion acts in a similar manner to physical massage, increasing permeability in deeply situated tissue [68-70]. The sonophoresis effect of ARF is also commonly utilised in transdermal drug delivery applications [71,72]. ARF has been shown to improve the tumoral uptake and effect of small-drug molecules [33,73-76]. However, as ARF is dependent upon energy absorption, it is best achieved with high intensities and/or frequencies. As such, it is necessary to consider the required treatment depth and pulse design to avoid excessive heating and tissue damage.

As indicated above, cavitation nucleating agents are also commonly used in drug delivery applications. Typically systemically administered, these reduce the intensity required for cavitation and other mechanical effects. Whilst many molecules and objects can act as ultrasound cavitation nuclei, the best studied and most clinically relevant types are microbubbles [77-83]. As microbubbles are highly echogenic, concurrent imaging can also be performed, allowing better target site recognition [84-87].

Typically, microbubbles consist of a high-molecular-weight gas core on the order of 1 to $10 \mu \mathrm{m}$ in diameter, encapsulated in a lipid, protein or, less commonly, a polymer shell [88]. In diagnostic imaging, their high compressibility and resonant behaviour causes significant linear and nonlinear scattering of incident acoustic waves [89], facilitating a number of imaging techniques [90-92]. It should be noted that microbubbles are vascular, or "blood pool", agents only. More recently, ultrasound-responsive nanodroplets of liquefied perfluorocarbons (PFCs) for drug delivery have 
shown an ability to extravasate in leaky tumours [93-95]. In addition, solid nanoparticles with entrained gas pockets are being used for similar purposes [96,97].

Cavitation agents can be driven to undergo stable oscillation or inertial collapse [98-100], depending upon the acoustic parameters and agent in use. In general, driving agents to inertial collapse is accepted as promoting the greatest drug delivery [101-104], leading to temporarily increased permeability [105] and delivery of any codelivered therapeutic [93,106-111]. However, the potential severity of blood vessel disruption [112] is undesirable in certain locations in the body, for instance, the brain $[113,114]$ or kidneys [115]. In these areas, stable oscillation generates sufficient shear stress to disrupt cell membranes [102] and increase vascular permeability [116]; particularly in the highly selective blood brain barrier [117] (see Figure 3), recently reviewed in [118,119]. Endocytotic pathways are also known to be activated by the acoustically driven shear stresses, and these are also implicated in delivery [120-123].

a)

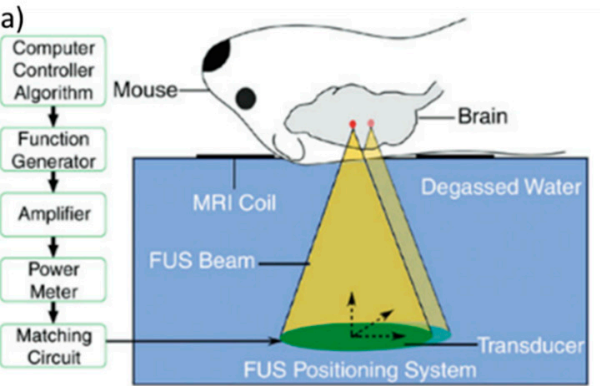

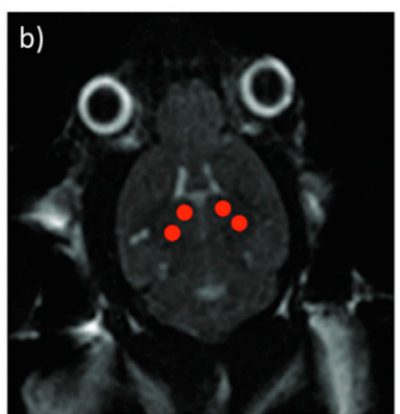

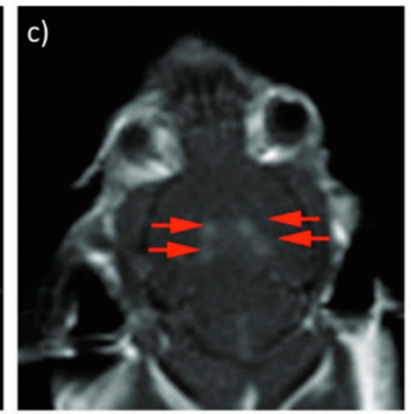

Figure 3. Opening the blood brain barrier (BBB) by focused ultrasound (FUS) and microbubbles in mice. The (a) setup utilises a coregistered magnetic resonance imaging (MRI) to identify targets in the brain. The targets in the mouse hippocampus are (b) marked on the image as red dots and FUS is applied after an injection of Definity ${ }^{\circledR}$ microbubbles. After treatment, a gadolinium-based MRI contrast agent is injected. Typically unable to cross the blood brain barrier, after treatment (c), an enhancement of contrast is seen at the target sites in the mouse hippocampus. Reprinted with permission from the Radiological Society of North America, Radiology [117].

In addition to coadministration, cavitation agents can be modified to load the drug of interest [124-127] or nanoparticle forms of the therapeutic (extensively reviewed in the literature [128-130]). In general, as permeability is only temporarily altered, colocalising the drug or nanocarrier to the site of microbubble activity promotes the delivery [131], effect [132], and release [133,134]. Finally, appropriate characterisation of the cavitation agent and drug loading is of vital importance to any drug delivery strategy (recently reviewed in [135]).

\section{Conclusions}

In the last 30 years, cancer survival rates have increased due to the better understanding of environmental risk factors, better diagnostic techniques, and improved therapies. However, drug-resistant cancers and toxic side-effects still represent significant barriers to successful treatment. Techniques to better localise existing chemotherapy drugs could vastly improve outcomes in these difficult cases. The combination of ultrasound and microbubbles has considerable potential as such a technique.

Author Contributions: Writing-Original Draft Preparation, R.J.B.; Writing—Review \& Editing, E.S.; Supervision, E.S.; Funding Acquisition, E.S.",

Funding: This research was funded by Pancreatic Cancer Research Fund.

Conflicts of Interest: The authors declare no conflict of interest. The funders had no role in the design of the study; in the collection, analyses, or interpretation of data; in the writing of the manuscript, and in the decision to publishs. 


\section{References}

1. World Health Organization (WHO). Cancer. Available online: http://www.who.int/cancer/en/ (accessed on 22 September 2018).

2. Horsman, M.R.; Overgaard, J. The impact of hypoxia and its modification of the outcome of radiotherapy. J. Radiat. Res. 2016, 57, i90-i98. [CrossRef] [PubMed]

3. Iyer, A.K.; Singh, A.; Ganta, S.; Amiji, M.M. Role of integrated cancer nanomedicine in overcoming drug resistance. Adv. Drug Deliv. Rev. 2013, 65, 1784-1802. [CrossRef] [PubMed]

4. Futreal, P.A.; Coin, L.; Marshall, M.; Down, T.; Hubbard, T.; Wooster, R.; Rahman, N.; Stratton, M.R. A census of human cancer genes. Nat. Rev. Cancer 2004, 4, 177-183. [CrossRef] [PubMed]

5. Prior, I.A.; Lewis, P.D.; Mattos, C. A comprehensive survey of ras mutations in cancer. Cancer Res. 2012, 72, 2457-2467. [CrossRef] [PubMed]

6. Carmeliet, P.; Jain, R.K. Angiogenesis in cancer and other diseases. Nature 2000, 407, 249-257. [CrossRef] [PubMed]

7. Hanahan, D.; Weinberg, R.A. The hallmarks of cancer. Cell 2000, 100, 57-70. [CrossRef]

8. Sriraman, S.K.; Aryasomayajula, B.; Torchilin, V.P. Barriers to drug delivery in solid tumors. Tissue Barriers 2014, 2, e29528. [CrossRef] [PubMed]

9. Curti, B.D. Physical barriers to drug delivery in tumors. Crit. Rev. Oncol. Hematol. 1993, 14, 29-39. [CrossRef]

10. Minchinton, A.I.; Tannock, I.F. Drug penetration in solid tumours. Nat. Rev. Cancer 2006, 6, 583-592. [CrossRef] [PubMed]

11. Dudley, A.C. Tumor endothelial cells. Cold Spring Harb. Perspect. Med. 2012, 2, a006536. [CrossRef] [PubMed]

12. Jain, R.K. Transport of molecules in the tumor interstitium: A review. Cancer Res. 1987, 47, 3039-3051. [PubMed]

13. Jain, R.K.; Baxter, L.T. Mechanisms of heterogeneous distribution of monoclonal antibodies and other macromolecules in tumors: Significance of elevated interstitial pressure. Cancer Res. 1988, 48, 7022-7032. [PubMed]

14. Onozuka, H.; Tsuchihara, K.; Esumi, H. Hypoglycemic/hypoxic condition in vitro mimicking the tumor microenvironment markedly reduced the efficacy of anticancer drugs. Cancer Sci. 2011, 102, 975-982. [CrossRef] [PubMed]

15. Rohwer, N.; Cramer, T. Hypoxia-mediated drug resistance: Novel insights on the functional interaction of hifs and cell death pathways. Drug Resist. Updat. 2011, 14, 191-201. [CrossRef] [PubMed]

16. Noble, J.A.; Boukerroui, D. Ultrasound image segmentation: A survey. IEEE Trans. Med. Imaging 2006, 25, 987-1010. [CrossRef] [PubMed]

17. Aaron, F.; Dónal, B.D.; Cardinal, H.N. Three-dimensional ultrasound imaging. Phys. Med. Biol. 2001, 46, R67.

18. Jean, P.; Clement, P.; Juan Esteban, A.; Marion, I.; Mathias, F.; Jean-Luc, G.; Mickael, T.; Mathieu, P. 3D ultrafast ultrasound imaging in vivo. Phys. Med. Biol. 2014, 59, L1-L13.

19. Vallancien, G.; Harouni, M.; Veillon, B.; Mombet, A.; Prapotnich, D.; Brisset, J.M.; Bougaran, J. Focused extracorporeal pyrotherapy: Feasibility study in man. J. Endourol. 1992, 6, 173-181. [CrossRef]

20. Tempany, C.M.C.; Stewart, E.A.; McDannold, N.; Quade, B.J.; Jolesz, F.A.; Hynynen, K. MR imaging-guided focused ultrasound surgery of uterine leiomyomas: A feasibility study. Radiology 2003, 226, 897-905. [CrossRef] [PubMed]

21. Stewart, E.A.; Gedroyc, W.M.W.; Tempany, C.M.C.; Quade, B.J.; Inbar, Y.; Ehrenstein, T.; Shushan, A.; Hindley, J.T.; Goldin, R.D.; David, M.; et al. Focused ultrasound treatment of uterine fibroid tumors: Safety and feasibility of a noninvasive thermoablative technique. Am. J. Obstet. Gynecol. 2003, 189, 48-54. [CrossRef] [PubMed]

22. Koes, B.W.; Bouter, L.M.; van Mameren, H.; Essers, A.H.M.; Verstegen, G.M.J.R.; Hofhuizen, D.M.; Houben, J.P.; Knipschild, P.G. Randomised clinical trial of manipulative therapy and physiotherapy for persistent back and neck complaints: Results of one year follow up. Br. Med. J. 1992, 304, 601-605. [CrossRef]

23. Airaksinen, O.; Brox, J.I.; Cedraschi, C.; Hildebrandt, J.; Klaber-Moffett, J.; Kovacs, F.; Mannion, A.F.; Reis, S.; Staal, J.B.; Ursin, H.; et al. Chapter 4 european guidelines for the management of chronic nonspecific low back pain. Eur. Spine J. 2006, 15, s192-s300. [CrossRef] [PubMed]

24. Mitragotri, S.; Edwards, D.A.; Blankschtein, D.; Langer, R. A mechanistic study of ultrasonically-enhanced transdermal drug delivery. J. Pharm. Sci. 1995, 84, 697-706. [CrossRef] [PubMed] 
25. Polat, B.E.; Blankschtein, D.; Langer, R. Low-frequency sonophoresis: Application to the transdermal delivery of macromolecules and hydrophilic drugs. Expert Opin. Drug Deliv. 2010, 7, 1415-1432. [CrossRef] [PubMed]

26. Park, D.; Park, H.; Seo, J.; Lee, S. Sonophoresis in transdermal drug deliverys. Ultrasonics 2014, 54, 56-65. [CrossRef] [PubMed]

27. Sauerbruch, T.; Delius, M.; Paumgartner, G.; Holl, J.; Wess, O.; Weber, W.; Hepp, W.; Brendel, W. Fragmentation of gallstones by extracorporeal shock waves. N. Engl. J. Med. 1986, 314, 818-822. [CrossRef] [PubMed]

28. Browning, R.J.; Rajkumar, V.; Pedley, R.B.; Eckersley, R.J.; Blower, P.J. Prospects for enhancement of targeted radionuclide therapy of cancer using ultrasound. J. Label. Compd. Radiopharm. 2014, 57, 279-284. [CrossRef] [PubMed]

29. Chu, K.F.; Dupuy, D.E. Thermal ablation of tumours: Biological mechanisms and advances in therapy. Nat. Rev. Cancer 2014, 14, 199-208. [CrossRef] [PubMed]

30. Hill, C.R.; Ter Haar, G.R. High intensity focused ultrasound-Potential for cancer treatment. Br. J. Radiol. 1995, 68, 1296-1303. [CrossRef] [PubMed]

31. Hynynen, K. Mrighifu: A tool for image-guided therapeutics. J. Magn. Reson. Imaging 2011, 34, $482-493$. [CrossRef] [PubMed]

32. Wu, F.; Wang, Z.B.; Cao, Y.D.; Chen, W.Z.; Bai, J.; Zou, J.Z.; Zhu, H. A randomised clinical trial of high-intensity focused ultrasound ablation for the treatment of patients with localised breast cancer. Br. J. Cancer 2003, 89, 2227-2233. [CrossRef] [PubMed]

33. Chen, X.; Cvetkovic, D.; Ma, C.M.; Chen, L. Quantitative study of focused ultrasound enhanced doxorubicin delivery to prostate tumor in vivo with mri guidance. Med. Phys. 2012, 39, 2780-2786. [CrossRef] [PubMed]

34. Staruch, R.M.; Ganguly, M.; Tannock, I.F.; Hynynen, K.; Chopra, R. Enhanced drug delivery in rabbit vx2 tumours using thermosensitive liposomes and mri-controlled focused ultrasound hyperthermia. Int. J. Hyperther. 2012, 28, 776-787. [CrossRef] [PubMed]

35. Lili, C.; Zhaomei, M.; Paul, H.; Ma, C.M.; Annie, W.; Alan, P. MR-guided focused ultrasound: Enhancement of intratumoral uptake of [3 h]-docetaxel in vivo. Phys. Med. Biol. 2010, 55, 7399-7410.

36. Paparel, P.; Chapelon, J.Y.; Bissery, A.; Chesnais, S.; Curiel, L.; Gelet, A. Influence of the docetaxel administration period (neoadjuvant or concomitant) in relation to hifu treatment on the growth of dunning tumors: Results of a preliminary study. Prostate Cancer Prostatic Dis. 2007, 11, 181-186. [CrossRef] [PubMed]

37. Wang, R.-S.; Liu, L.-X.; Gu, Y.-H.; Lin, Q.-F.; Guo, R.-H.; Shu, Y.-Q. The effect of endostatin and gemcitabine combined with hifu on the animal xenograft model of human pancreatic cancer. Biomed. Pharmacother. 2010, 64, 309-312. [CrossRef] [PubMed]

38. Paparel, P.; Curiel, L.; Chesnais, S.; Ecochard, R.; Chapelon, J.-Y.; Gelet, A. Synergistic inhibitory effect of high-intensity focused ultrasound combined with chemotherapy on dunning adenocarcinoma. BJU Int. 2005, 95, 881-885. [CrossRef] [PubMed]

39. Yu, T.; Zhang, Y.; He, H.; Zhou, S.; Liu, Y.; Huang, P. Anticancer potency of cytotoxic drugs after exposure to high-intensity focused ultrasound in the presence of microbubbles and hematoporphyrin. Mol. Pharm. 2011, 8, 1408-1415. [CrossRef] [PubMed]

40. Zhang, T.; Chen, L.; Zhang, S.; Xu, Y.; Fan, Y.; Zhang, L. Effects of high-intensity focused ultrasound on cisplatin-resistant human lung adenocarcinoma in vitro and in vivo. Acta Biochim. Biophys. Sin. 2017, 49, 1092-1098. [CrossRef] [PubMed]

41. Lee, Y.-Y.; Cho, Y.J.; Choi, J.-J.; Choi, C.H.; Kim, T.-J.; Kim, B.-G.; Bae, D.-S.; Kim, Y.-S.; Lee, J.-W. The effect of high-intensity focused ultrasound in combination with cisplatin using a xenograft model of cervical cancer. Anticancer Res. 2012, 32, 5285-5289. [PubMed]

42. Zhao, H.; Yang, G.; Wang, D.; Yu, X.; Zhang, Y.; Zhu, J.; Ji, Y.; Zhong, B.; Zhao, W.; Yang, Z.; et al. Concurrent gemcitabine and high-intensity focused ultrasound therapy in patients with locally advanced pancreatic cancer. Anticancer Drugs 2010, 21, 447-452. [CrossRef] [PubMed]

43. Lv, W.; Yan, T.; Wang, G.; Zhao, W.; Zhang, T.; Zhou, D. High-intensity focused ultrasound therapy in combination with gemcitabine for unresectable pancreatic carcinoma. Ther. Clin. Risk Manag. 2016, 12, 687-691. [PubMed]

44. Dudar, T.E.; Jain, R.K. Differential response of normal and tumor microcirculation to hyperthermia. Cancer Res. 1984, 44, 605-612. [PubMed] 
45. Bischof, J.C.; Padanilam, J.; Holmes, W.H.; Ezzell, R.M.; Lee, R.C.; Tompkins, R.G.; Yarmush, M.L.; Toner, M. Dynamics of cell membrane permeability changes at supraphysiological temperatures. Biophys. J. 1995, 68, 2608-2614. [CrossRef]

46. Marmor, J.B. Interactions of hyperthermia and chemotherapy in animals. Cancer Res. 1979, 39, $2269-2276$. [PubMed]

47. Los, G.; van Vugt, M.J.H.; Pinedo, H.M. Response of peritoneal solid tumours after intraperitoneal chemohyperthermia treatment with cisplatin or carboplatin. Br. J. Cancer 1994, 69, 235-241. [CrossRef] [PubMed]

48. Elias, D.; Bonnay, M.; Puizillou, J.M.; Antoun, S.; Demirdjian, S.; El Otmany, A.; Pignon, J.P.; Drouard-Troalen, L.; Ouellet, J.F.; Ducreux, M. Heated intra-operative intraperitoneal oxaliplatin after complete resection of peritoneal carcinomatosis: Pharmacokinetics and tissue distribution. Ann. Oncol. 2002, 13, 267-272. [CrossRef] [PubMed]

49. Sen, A.; Capitano, M.L.; Spernyak, J.A.; Schueckler, J.T.; Thomas, S.; Singh, A.K.; Evans, S.S.; Hylander, B.L.; Repasky, E.A. Mild elevation of body temperature reduces tumor interstitial fluid pressure and hypoxia and enhances efficacy of radiotherapy in murine tumor models. Cancer Res. 2011, 71, 3872-3880. [CrossRef] [PubMed]

50. Vaupel, P.; Horsman, M.R. Tumour perfusion and associated physiology: Characterization and significance for hyperthermia. Int. J. Hyperther. 2010, 26, 209-210. [CrossRef] [PubMed]

51. Werthmöller, N.; Frey, B.; Rückert, M.; Lotter, M.; Fietkau, R.; Gaipl, U.S. Combination of ionising radiation with hyperthermia increases the immunogenic potential of b16-f10 melanoma cells in vitro and in vivo. Int. J. Hyperther. 2016, 32, 23-30. [CrossRef] [PubMed]

52. Bull, J.M.C. A review of immune therapy in cancer and a question: Can thermal therapy increase tumor response? Int. J. Hyperther. 2018, 34, 840-852. [CrossRef] [PubMed]

53. Grüll, H.; Langereis, S. Hyperthermia-triggered drug delivery from temperature-sensitive liposomes using mri-guided high intensity focused ultrasound. J. Control. Release 2012, 161, 317-327. [CrossRef] [PubMed]

54. Browning, R.J.; Reardon, P.J.T.; Parhizkar, M.; Pedley, R.B.; Edirisinghe, M.; Knowles, J.C.; Stride, E. Drug delivery strategies for platinum-based chemotherapy. ACS Nano 2017, 11, 8560-8578. [CrossRef] [PubMed]

55. Moy, A.J.; Tunnell, J.W. Combinatorial immunotherapy and nanoparticle mediated hyperthermia. Adv. Drug Deliv. Rev. 2017, 114, 175-183. [CrossRef] [PubMed]

56. You, Y.; Wang, Z.; Ran, H.; Zheng, Y.; Wang, D.; Xu, J.; Wang, Z.; Chen, Y.; Li, P. Nanoparticle-enhanced synergistic hifu ablation and transarterial chemoembolization for efficient cancer therapy. Nanoscale 2016, 8 , 4324-4339. [CrossRef] [PubMed]

57. Kopechek, J.A.; Park, E.; Mei, C.-S.; McDannold, N.J.; Porter, T.M. Accumulation of phase-shift nanoemulsions to enhance mr-guided ultrasound-mediated tumor ablation in vivo. J. Healthc. Eng. 2013, 4, 109-126. [CrossRef] [PubMed]

58. Xi, J.; Qian, X.; Qian, K.; Zhang, W.; He, W.; Chen, Y.; Han, J.; Zhang, Y.; Yang, X.; Fan, L. Au nanoparticle-coated, plga-based hybrid capsules for combined ultrasound imaging and hifu therapy. J. Mater. Chem. B 2015, 3, 4213-4220. [CrossRef]

59. Sun, Y.; Zheng, Y.; Ran, H.; Zhou, Y.; Shen, H.; Chen, Y.; Chen, H.; Krupka, T.M.; Li, A.; Li, P.; et al. Superparamagnetic plga-iron oxide microcapsules for dual-modality us/mr imaging and high intensity focused us breast cancer ablation. Biomaterials 2012, 33, 5854-5864. [CrossRef] [PubMed]

60. Thiriet, M.; Solovchuk, M.; Sheu, T.W.-H. Hifu treatment of liver cancer-Reciprocal effect of blood flow and us studied from a patient-specific configuration. In Computational Modeling of Objects Presented in Images. Fundamentals, Methods, and Applications: 4th International Conference, CompIMAGE 2014; Zhang, Y.J., Tavares, J.M.R.S., Eds.; Springer International Publishing: Pittsburgh, PA, USA, 2014; pp. 1-11.

61. Harriet, L.-B.; Boon, T.; Eleanor, S.; Constantin, C.C. The effect of particle density on ultrasound-mediated transport of nanoparticles. Phys. Med. Biol. 2016, 61, 7906-7918.

62. Raghavan, R. Theory for acoustic streaming in soft porous matter and its applications to ultrasound-enhanced convective delivery. J. Ther. Ultrasound 2018, 6, 6. [CrossRef] [PubMed]

63. Seidl, M.; Steinbach, P.; Wörle, K.; Hofstädter, F. Induction of stress fibres and intercellular gaps in human vascular endothelium by shock-waves. Ultrasonics 1994, 32, 397-400. [CrossRef] 
64. Hancock, H.A.; Smith, L.H.; Cuesta, J.; Durrani, A.K.; Angstadt, M.; Palmeri, M.L.; Kimmel, E.; Frenkel, V. Investigations into pulsed high-intensity focused ultrasound-enhanced delivery: Preliminary evidence for a novel mechanism. Ultrasound Med. Biol. 2009, 35, 1722-1736. [CrossRef] [PubMed]

65. Alonso, A.; Reinz, E.; Jenne, J.W.; Fatar, M.; Schmidt-Glenewinkel, H.; Hennerici, M.G.; Meairs, S. Reorganization of gap junctions after focused ultrasound blood-brain barrier opening in the rat brain. J. Cereb. Blood Flow Metab. 2010, 30, 1394-1402. [CrossRef] [PubMed]

66. O'Neill, B.E.; Vo, H.; Angstadt, M.; Li, K.P.C.; Quinn, T.; Frenkel, V. Pulsed high intensity focused ultrasound mediated nanoparticle delivery: Mechanisms and efficacy in murine muscle. Ultrasound Med. Biol. 2009, 35, 416-424. [CrossRef] [PubMed]

67. Mesiwala, A.H.; Farrell, L.; Wenzel, H.J.; Silbergeld, D.L.; Crum, L.A.; Winn, H.R.; Mourad, P.D. High-intensity focused ultrasound selectively disrupts the blood-brain barrier in vivo. Ultrasound Med. Biol. 2002, 28, 389-400. [CrossRef]

68. Lizzi, F.L.; Muratore, R.; Deng, C.X.; Ketterling, J.A.; Alam, S.K.; Mikaelian, S.; Kalisz, A. Radiation-force technique to monitor lesions during ultrasonic therapy. Ultrasound Med. Biol. 2003, 29, 1593-1605. [CrossRef]

69. Frenkel, V.; Deng, C.; O’Neill, B.E.; Quijano, J.; Stone, M.J.; Dromi, S.; Hunter, F.; Xie, J.; Quinn, T.P.; Wood, B.J.; et al. Pulsed-high intensity focused ultrasound (hifu) exposures for enhanced delivery of therapeutics: Mechanisms and applications. AIP Conf. Proc. 2006, 829, 528-532.

70. Palmeri, M.L.; Sharma, A.C.; Bouchard, R.R.; Nightingale, R.W.; Nightingale, K.R. A finite-element method model of soft tissue response to impulsive acoustic radiation force. IEEE Trans. Ultrason. Ferroelectr. Freq. Control 2005, 52, 1699-1712. [CrossRef] [PubMed]

71. Ita, K. Percutaneous penetration of anticancer agents: Past, present and future. Biomed. Pharmacother. 2016, 84, 1428-1439. [CrossRef] [PubMed]

72. Prausnitz, M.R.; Langer, R. Transdermal drug delivery. Nat. Biotechnol. 2008, 26, 1261-1268. [CrossRef] [PubMed]

73. Park, M.J.; Kim, Y.-S.; Yang, J.; Sun, W.C.; Park, H.; Chae, S.Y.; Namgung, M.-S.; Choi, K.-S. Pulsed high-intensity focused ultrasound therapy enhances targeted delivery of cetuximab to colon cancer xenograft model in mice. Ultrasound Med. Biol. 2013, 39, 292-299. [CrossRef] [PubMed]

74. Frenkel, V.; Etherington, A.; Greene, M.; Quijano, J.; Xie, J.; Hunter, F.; Dromi, S.; Li, K.C.P. Delivery of liposomal doxorubicin (doxil) in a breast cancer tumor model: Investigation of potential enhancement by pulsed-high intensity focused ultrasound exposure. Acad. Radiol. 2006, 13, 469-479. [CrossRef] [PubMed]

75. Larkin, J.O.; Casey, G.D.; Tangney, M.; Cashman, J.; Collins, C.G.; Soden, D.M.; O'Sullivan, G.C. Effective tumor treatment using optimized ultrasound-mediated delivery of bleomycin. Ultrasound Med. Biol. 2008, 34, 406-413. [CrossRef] [PubMed]

76. Park, E.-J.; Ahn, Y.D.; Lee, J.Y. In vivo study of enhanced chemotherapy combined with ultrasound image-guided focused ultrasound (usgfus) treatment for pancreatic cancer in a xenograft mouse model. Eur. Radiol. 2018, 28, 3710-3718. [CrossRef] [PubMed]

77. Sponheim, N.; Hoff, L.; Waaler, A.; Muan, B.; Morris, H.; Holm, S.; Myrum, M.; de Jong, N.; Skotland, T. Albunex-a new ultrasound contrast agent. In Proceedings of the International Conference onAcoustic Sensing and Imaging, London, UK, 29-30 March 1993; pp. 103-108.

78. De Jong, N. Improvements in ultrasound contrast agents. IEEE Eng. Med. Biol. Mag. 1994, 15, 72-82. [CrossRef]

79. Christiansen, C.; Vebner, A.J.; Muan, B.; Vik, H.; Haider, T.; Nicolaysen, H.; Skotland, T. Lack of an immune response to albunex, a new ultrasound contrast agent based on air-filled albumin microspheres. Int. Arch. Allergy Immunol. 1994, 104, 372-378. [CrossRef] [PubMed]

80. Schneider, M.; Arditi, M.; Barrau, M.-B.; Brochot, J.; Broillet, A.; Ventrone, R.; Yan, F. BR1: A new ultrasonographic contrast agent based on sulfur hexafluoride-filled microbubbles. Investig. Radiol. 1995, 30, 451-457. [CrossRef]

81. Schneider, M. Sonovue, a new ultrasound contrast agent. Eur. Radiol. 1999, 9, S347-S348. [CrossRef] [PubMed]

82. Schneider, M. Characteristics of sonovue ${ }^{\mathrm{TM}}$. Echocardiography 1999, 16, 743-746. [CrossRef] [PubMed]

83. Deng, C.X.; Sieling, F.; Pan, H.; Cui, J. Ultrasound-induced cell membrane porosity. Ultrasound Med. Biol. 2004, 30, 519-526. [CrossRef] [PubMed] 
84. Browning, R.J.; Mulvana, H.; Tang, M.; Hajnal, J.V.; Wells, D.J.; Eckersley, R.J. Influence of needle gauge on in vivo ultrasound and microbubble-mediated gene transfection. Ultrasound Med. Biol. 2011, 37, 1531-1537. [CrossRef] [PubMed]

85. Browning, R.J.; Mulvana, H.; Tang, M.-X.; Hajnal, J.V.; Wells, D.J.; Eckersley, R.J. Effect of albumin and dextrose concentration on ultrasound and microbubble mediated gene transfection in vivo. Ultrasound Med. Biol. 2012, 38, 1067-1077. [CrossRef] [PubMed]

86. Alter, J.; Sennoga, C.A.; Lopes, D.M.; Eckersley, R.J.; Wells, D.J. Microbubble stability is a major determinant of the efficiency of ultrasound and microbubble mediated in vivo gene transfer. Ultrasound Med. Biol. 2009, 35, 976-984. [CrossRef] [PubMed]

87. Fokong, S.; Theek, B.; Wu, Z.; Koczera, P.; Appold, L.; Jorge, S.; Resch-Genger, U.; van Zandvoort, M.; Storm, G.; Kiessling, F.; et al. Image-guided, targeted and triggered drug delivery to tumors using polymer-based microbubbles. J. Control. Release 2012, 163, 75-81. [CrossRef] [PubMed]

88. Sirsi, S.R.; Borden, M.A. State-of-the-art materials for ultrasound-triggered drug delivery. Adv. Drug Deliv. Rev. 2014, 72, 3-14. [CrossRef] [PubMed]

89. Morgan, K.E.; Allen, J.S.; Dayton, P.A.; Chomas, J.E.; Klibanov, A.L.; Ferrara, K.W. Experimental and theoretical evaluation of microbubble behavior: Effect of transmitted phase and bubble size. IEEE Trans. Ultrason. Ferroelectr. Freq. Control 2000, 47, 1494-1509. [CrossRef] [PubMed]

90. Christensen-Jeffries, K.; Browning, R.J.; Meng-Xing, T.; Dunsby, C.; Eckersley, R.J. In vivo acoustic super-resolution and super-resolved velocity mapping using microbubbles. IEEE Trans. Med. Imaging 2015, 34, 433-440. [CrossRef] [PubMed]

91. Couture, O.; Hingot, V.; Heiles, B.; Muleki-Seya, P.; Tanter, M. Ultrasound localization microscopy and super-resolution: A state of the art. IEEE Trans. Ultrason. Ferroelectr. Freq. Control 2018, 65, 1304-1320. [CrossRef] [PubMed]

92. Mehta, K.S.; Lee, J.J.; Taha, A.A.; Avgerinos, E.; Chaer, R.A. Vascular applications of contrast-enhanced ultrasound imaging. J. Vasc. Surg. 2017, 66, 266-274. [CrossRef] [PubMed]

93. Rapoport, N.Y.; Kennedy, A.M.; Shea, J.E.; Scaife, C.L.; Nam, K.-H. Controlled and targeted tumor chemotherapy by ultrasound-activated nanoemulsions/microbubbles. J. Control. Release 2009, 138, 268-276. [CrossRef] [PubMed]

94. Rapoport, N.; Nam, K.-H.; Gupta, R.; Gao, Z.; Mohan, P.; Payne, A.; Todd, N.; Liu, X.; Kim, T.; Shea, J.; et al. Ultrasound-mediated tumor imaging and nanotherapy using drug loaded, block copolymer stabilized perfluorocarbon nanoemulsions. J. Control. Release 2011, 153, 4-15. [CrossRef] [PubMed]

95. Du, L.; Jin, Y.; Zhou, W.; Zhao, J. Ultrasound-triggered drug release and enhanced anticancer effect of doxorubicin-loaded poly(D,L-lactide-co-glycolide)-methoxy-poly(ethylene glycol) nanodroplets. Ultrasound Med. Biol. 2011, 37, 1252-1258. [CrossRef] [PubMed]

96. Bhatnagar, S.; Kwan, J.J.; Shah, A.R.; Coussios, C.-C.; Carlisle, R.C. Exploitation of sub-micron cavitation nuclei to enhance ultrasound-mediated transdermal transport and penetration of vaccines. J. Control. Release 2016, 238, 22-30. [CrossRef] [PubMed]

97. Kwan, J.J.; Myers, R.; Coviello, C.M.; Graham, S.M.; Shah, A.R.; Stride, E.; Carlisle, R.C.; Coussios, C.C. Ultrasound-propelled nanocups for drug delivery. Small 2015, 11, 5305-5314. [CrossRef] [PubMed]

98. Loughran, J.; Eckersley, R.J.; Tang, M.-X. Modeling non-spherical oscillations and stability of acoustically driven shelled microbubbles. J. Acoust. Soc. Am. 2012, 131, 4349-4357. [CrossRef] [PubMed]

99. Hoff, L.; Sontum, P.C.; Hovem, J.M. Oscillations of polymeric microbubbles: Effect of the encapsulating shell. J. Acoust. Soc. Am. 2000, 107, 2272-2280. [CrossRef] [PubMed]

100. Sboros, V. Response of contrast agents to ultrasound. Adv. Drug Deliv. Rev. 2008, 60, 1117-1136. [CrossRef] [PubMed]

101. Tachibana, K.; Tachibana, S. The use of ultrasound for drug delivery. Echocardiography 2001, 18, $323-328$. [CrossRef] [PubMed]

102. Van Wamel, A.; Kooiman, K.; Harteveld, M.; Emmer, M.; ten Cate, F.J.; Versluis, M.; de Jong, N. Vibrating microbubbles poking individual cells: Drug transfer into cells via sonoporation. J. Control. Release 2006, 112, 149-155. [CrossRef] [PubMed]

103. Bekeredjian, R.; Grayburn, P.A.; Shohet, R.V. Use of ultrasound contrast agents for gene or drug delivery in cardiovascular medicine. J. Am. Coll. Cardiol. 2005, 45, 329-335. [CrossRef] [PubMed] 
104. Hernot, S.; Klibanov, A.L. Microbubbles in ultrasound-triggered drug and gene delivery. Adv. Drug Deliv. Rev. 2008, 60, 1153-1166. [CrossRef] [PubMed]

105. Yang, F.Y.; Wang, H.E.; Lin, G.L.; Lin, H.H.; Wong, T.T. Evaluation of the increase in permeability of the blood-brain barrier during tumor progression after pulsed focused ultrasound. Int. J. Nanomed. 2012, 7, 723-730. [CrossRef] [PubMed]

106. Dimcevski, G.; Kotopoulis, S.; Bjånes, T.; Hoem, D.; Schjøtt, J.; Gjertsen, B.T.; Biermann, M.; Molven, A.; Sorbye, H.; McCormack, E.; et al. A human clinical trial using ultrasound and microbubbles to enhance gemcitabine treatment of inoperable pancreatic cancer. J. Control. Release 2016, 243, 172-181. [CrossRef] [PubMed]

107. Lentacker, I.; Geers, B.; Demeester, J.; De Smedt, S.C.; Sanders, N.N. Design and evaluation of doxorubicin-containing microbubbles for ultrasound-triggered doxorubicin delivery: Cytotoxicity and mechanisms involved. Mol. Ther. 2009, 18, 101-108. [CrossRef] [PubMed]

108. Lentacker, I.; De Smedt, S.C.; Sanders, N.N. Drug loaded microbubble design for ultrasound triggered delivery. Soft Matter 2009, 5, 2161-2170. [CrossRef]

109. Rapoport, N.; Gao, Z.; Kennedy, A. Multifunctional nanoparticles for combining ultrasonic tumor imaging and targeted chemotherapy. J. Natl. Cancer Inst. 2007, 99, 1095-1106. [CrossRef] [PubMed]

110. Li, P.; Zheng, Y.; Ran, H.; Tan, J.; Lin, Y.; Zhang, Q.; Ren, J.; Wang, Z. Ultrasound triggered drug release from 10-hydroxycamptothecin-loaded phospholipid microbubbles for targeted tumor therapy in mice. J. Control. Release 2012, 162, 349-354. [CrossRef] [PubMed]

111. Matsuo, M.; Yamaguchi, K.; Feril Jr, L.B.; Endo, H.; Ogawa, K.; Tachibana, K.; Nakayama, J. Synergistic inhibition of malignant melanoma proliferation by melphalan combined with ultrasound and microbubbles. Ultrason. Sonochem. 2011, 18, 1218-1224. [CrossRef] [PubMed]

112. Sanches, P.G.; Rossin, R.; Böhmer, M.; Tiemann, K.; Grüll, H. Real-time imaging and kinetics measurements of focused ultrasound-induced extravasation in skeletal muscle using spect/ct. J. Control. Release 2013, 168, 262-270. [CrossRef] [PubMed]

113. Yao-Sheng, T.; Fotios, V.; James, J.C.; Thomas, D.; Kirsten, S.; Elisa, E.K. In vivo transcranial cavitation threshold detection during ultrasound-induced blood-brain barrier opening in mice. Phys. Med. Biol. 2010, $55,6141-6155$.

114. McDannold, N.; Vykhodtseva, N.; Hynynen, K. Targeted disruption of the blood-brain barrier with focused ultrasound: Association with cavitation activity. Phys. Med. Biol. 2006, 51, 793-807. [CrossRef] [PubMed]

115. Wible, J.H.; Galen, K.P.; Wojdyla, J.K.; Hughes, M.S.; Klibanov, A.L.; Brandenburger, G.H. Microbubbles induce renal hemorrhage when exposed to diagnostic ultrasound in anesthetized rats. Ultrasound Med. Biol. 2002, 28, 1535-1546. [CrossRef]

116. Timbie, K.; Zhang, C.; Nance, E.; Song, J.; Miller, W.; Hanes, J.; Price, R. Ultrasound-mediated delivery of brain-penetrating nanoparticles across the blood-tumor barrier. J. Ther. Ultrasound 2015, 3, P34. [CrossRef]

117. Burgess, A.; Dubey, S.; Yeung, S.; Hough, O.; Eterman, N.; Aubert, I.; Hynynen, K. Alzheimer disease in a mouse model: Mr imaging-guided focused ultrasound targeted to the hippocampus opens the blood-brain barrier and improves pathologic abnormalities and behavior. Radiology 2014, 273, 736-745. [CrossRef] [PubMed]

118. Burgess, A.; Shah, K.; Hough, O.; Hynynen, K. Focused ultrasound-mediated drug delivery through the blood-brain barrier. Expert Rev. Neurother. 2015, 15, 477-491. [CrossRef] [PubMed]

119. Meng, Y.; Suppiah, S.; Surendrakumar, S.; Bigioni, L.; Lipsman, N. Low-intensity mr-guided focused ultrasound mediated disruption of the blood-brain barrier for intracranial metastatic diseases. Front. Oncol. 2018, 8, 338. [CrossRef] [PubMed]

120. Schlicher, R.K.; Radhakrishna, H.; Tolentino, T.P.; Apkarian, R.P.; Zarnitsyn, V.; Prausnitz, M.R. Mechanism of intracellular delivery by acoustic cavitation. Ultrasound Med. Biol. 2006, 32, 915-924. [CrossRef] [PubMed]

121. Lentacker, I.; Wang, N.; Vandenbroucke, R.E.; Demeester, J.; De Smedt, S.C.; Sander, N.N. Ultrasound exposure of lipoplex loaded microbubbles facilitates direct cytoplasmic entry of the lipoplexes. Mol. Pharm. 2009, 6, 457-467. [CrossRef] [PubMed]

122. Walton, C.B.; Shohet, R.V. Tiny bubbles and endocytosis? Circ. Res. 2009, 104, 563-565. [CrossRef] [PubMed]

123. Meijering, B.D.M.; Juffermans, L.J.M.; van Wamel, A.; Henning, R.H.; Zuhorn, I.S.; Emmer, M.; Versteilen, A.M.G.; Paulus, W.J.; van Gilst, W.H.; Kooiman, K.; et al. Ultrasound and microbubble-targeted delivery of macromolecules is regulated by induction of endocytosis and pore formation. Circ. Res. 2009, 104, 679-687. [CrossRef] [PubMed] 
124. Chumakova, O.V.; Liopo, A.V.; Andreev, V.G.; Cicenaite, I.; Evers, B.M.; Chakrabarty, S.; Pappas, T.C.; Esenaliev, R.O. Composition of plga and pei/DNA nanoparticles improves ultrasound-mediated gene delivery in solid tumors in vivo. Cancer Lett. 2008, 261, 215-225. [CrossRef] [PubMed]

125. Yang, H.; Deng, L.; Li, T.; Shen, X.; Yan, J.; Zuo, L.; Wu, C.; Liu, Y. Multifunctional plga nanobubbles as theranostic agents: Combining doxorubicin and p-gp sirna co-delivery into human breast cancer cells and ultrasound cellular imaging. J. Biomed. Nanotechnol. 2015, 11, 2124-2136. [CrossRef] [PubMed]

126. Eggen, S.; Fagerland, S.-M.; Mørch, Ý.; Hansen, R.; Søvik, K.; Berg, S.; Furu, H.; Bøhn, A.D.; Lilledahl, M.B.; Angelsen, A.; et al. Ultrasound-enhanced drug delivery in prostate cancer xenografts by nanoparticles stabilizing microbubbles. J. Control. Release 2014, 187, 39-49. [CrossRef] [PubMed]

127. Nesbitt, H.; Sheng, Y.; Kamila, S.; Logan, K.; Thomas, K.; Callan, B.; Taylor, M.A.; Love, M.; O’Rourke, D.; Kelly, P.; et al. Gemcitabine loaded microbubbles for targeted chemo-sonodynamic therapy of pancreatic cancer. J. Control. Release 2018, 279, 8-16. [CrossRef] [PubMed]

128. Mullin, L.B.; Phillips, L.C.; Dayton, P.A. Nanoparticle delivery enhancement with acoustically activated microbubbles. IEEE Trans. Ultrason. Ferroelectr. Freq. Control 2013, 60, 65-77. [CrossRef] [PubMed]

129. Zheng, S.-G.; Xu, H.-X.; Chen, H.-R. Nano/microparticles and ultrasound contrast agents. World J. Radiol. 2013, 5, 468-471. [CrossRef] [PubMed]

130. Figueiredo, M.; Esenaliev, R. Plga nanoparticles for ultrasound-mediated gene delivery to solid tumors. J. Drug Deliv. 2012, 2012, 1-20. [CrossRef] [PubMed]

131. Burke, C.W.; Hsiang, Y.-H.J.; Alexander, E.; Kilbanov, A.L.; Price, R.J. Covalently linking poly(lactic-coglycolic acid) nanoparticles to microbubbles before intravenous injection improves their ultrasound-targeted delivery to skeletal muscle. Small 2011, 7, 1227-1235. [CrossRef] [PubMed]

132. Burke, C.W.; Alexander, E.; Timbie, K.; Kilbanov, A.L.; Price, R.J. Ultrasound-activated agents comprised of 5 fu-bearing nanoparticles bonded to microbubbles inhibit solid tumor growth and improve survival. Mol. Ther. 2014, 22, 321-328. [CrossRef] [PubMed]

133. Wu, P.; Jia, Y.; Qu, F.; Sun, Y.; Wang, P.; Zhang, K.; Xu, C.; Liu, Q.; Wang, X. Ultrasound-responsive polymeric micelles for sonoporation-assisted site-specific therapeutic action. ACS Appl. Mater. Interfaces 2017, 9, 25706-25716. [CrossRef] [PubMed]

134. Kamaly, N.; Yameen, B.; Wu, J.; Farokhzad, O.C. Degradable controlled-release polymers and polymeric nanoparticles: Mechanisms of controlling drug release. Chem. Rev. 2016, 116, 2602-2663. [CrossRef] [PubMed]

135. Mulvana, H.; Browning, R.J.; Luan, Y.; Jong, N.D.; Tang, M.X.; Eckersley, R.J.; Stride, E. Characterization of contrast agent microbubbles for ultrasound imaging and therapy research. IEEE Trans. Ultrason. Ferroelectr. Freq. Control 2017, 64, 232-251. [CrossRef] [PubMed] 